\title{
PERTUMBUHAN LABA PADA LEMBAGA PERKREDITAN DESA
}

\author{
I Ketut Sujana ${ }^{1}$ \\ I Made Sadha Suardikha ${ }^{2}$ \\ A.A.N.B. Dwirandra ${ }^{3}$ \\ ${ }^{1,2,3}$ Fakultas Ekonomi dan Bisnis, Universitas Udayana, Bali, Indonesia \\ email: ketutsujana_fe@yahoo.com
}

\begin{abstract}
ABSTRAK
Lembaga Perkreditan Desa (LPD) beroperasi seperti perbankan dan pengukuran kinerja (tingkat kesehatannya) seperti bank, walaupun LPD tersebut bukanlah bank. Pertumbuhan laba yang positif mencerminkan LPD mampu berkembang dalam operasionalnya.Penelitian bertujuan mengetahui pengaruh Capital, Asset, Earning, Liquidity (CAEL) dan Non Performing Loan (NPL) memengaruhi pertumbuhan laba pada LPD. Studi empiris dilakukan pada LPD di Kabupaten Badung Provinsi Bali periode 2013-2015 dengan jumlah sampel 53 LPD. Data penelitian adalah data sekunder yang diperoleh dari Lembaga Pemberdayaan Lembaga Perkreditan Desa Kabupaten (LPLPDK) Badung dan beberapa dari LPD secara langsung. Teknik analisis menggunakan regresi linier berganda. Hasil penelitian menunjukkan bahwa BOPO berpengaruh negatif terhadap pertumbuhan laba. Sedangkan CAR, KAP, PPAP, ROA, LACLR, LDR dan NPL tidak berpengaruh terhadap pertumbuhan laba.
\end{abstract}

Kata kunci: Lembaga Pertumbuhan Desa, CAEL, NPL, pertumbuhan laba

\section{PROFIT GROWTH AT VILLAGE CREDIT INSTITUTION (LPD)}

\section{ABSTRACT}

Village Credit Institution (LPD) operates as banking and the performance measurement (for the health level) is like a bank, although LPD is not a bank. The positive profit growth reflects the LPD will be able to grow in its operations. This research has objectives to determine the effect of Capital, Asset, Earning, Liquidity (CAEL) and Non Performing Loan (NPL) to affect the profit growth in LPD. Empirical studies were conducted on LPDs in Badung-Bali Regency in the period of 2013-2015 with the sample amount of 53 LPDs. The data used in this research is secondary data, which was obtained from Lembaga Pemberdayaan Lembaga Perkreditan Desa Kabupaten (LPLPDK) Badung and some were obtained from LPD directly. The analysis technique used is multiple linear regressions. The result in this research showed that BOPO has negatif effect to the profit growth. Meanwhile, CAR, KAP, PPAP, ROA, LACLR, LDR, and NPL do not significantly affect the profit growth.

Keywords:Village Credit Institution (LPD), CAEL, NPL, profit growth

DOI: https://doi.org/10.24843/JIAB.2018.v13.i02.p11

\section{PENDAHULUAN}

Bali memiliki suatu lembaga keuangan yang unik pada komunitas desa adat yang disebut desa pakraman. Lembaga keuangan ini bernama Lembaga Perkreditan Desa (LPD). LPD sebagai lembaga keuangan Eksistensi atau legitimasi LPD berdasarkan Keputusan Gubernur Kepala Daerah Tingkat I Bali No. 972 Tahun 1984 dan Undang-Undang Republik Indonesia Nomor 1 Tahun 2013 Tentang Lembaga Keuangan Mikro, khususnya Pasal 39 tertera bahwa LPD diakui berdasarkan hukum adat.

Dalam pararem LPD Bali tahun 2014, salah satu tujuan LPD adalah memperkuat ketahanan desa pakraman dalam melestarikan dan menumbuh kembangkan nilai-nilai luhur adat dan budaya Bali. Nurjaya (2011:26), LPD yang beroperasi tidak semata-mata bergerak di ranah sosial ekonomi tetapi ada misi menjaga kehidupan budaya serta dimensi hubungan manusia dengan Tuhan (ajaran Tri Hita Karana/THK). Hal ini didukung oleh Sudarma (2013) yang menemukan bahwa terdapat indeksikalitas nilai budaya THK pada LPD di Denpasar-Bali. Begitu pula, Negara dan Sujana (2014) mengungkapkan bahwa LPD sebagai tiang penyangga adat dan budaya Bali merupakan salah satu aset bangsa. LPD 
menyediakan dana untuk operasional serta dalam rangka mencapai tujuan memberikan manfaat kepada warga desa pakraman.

Salah satu sumber dana untuk mendukung pencapaian tujuan tersebut bersumber dari distribusi laba LPD. Pembagian laba LPD ke desa pakraman dapat digunakan untuk membina dan mengembangkan nilai-nilai budaya THK dalam rangka memperkaya, melestarikan, dan mengembangkan kebudayaan daerah Bali khususnya dan kebudayaan nasional umumnya sebagai penanda identitas bangsa. Demikian pula,distribusi laba dapat digunakan oleh desa pakraman untuk memenuhi kebutuhan desa dari segi finansial dalam mewujudkan misi fungsionalnya sebagai tiang peradaban, seperti penyelenggaraan upacara dan kegiatan keagamaan dengan berbagai instrumen ritualnya, memelihara kebutuhan hidup sesama serta memelihara alam lingkungan.Oleh karenanya, perlu diketahui faktor-faktor yang mampu mempengaruhi pertumbuhan labanya. Pertumbuhan laba yang positif mengindikasikan bahwa LPD berkembang dan mampu melaksanakan fungsinya.

Secara fungsional, aktivitas LPD tidak beda dengan Bank Perkreditan Rakyat (BPR), yakni menerima dana simpanan dari masyarakat dan dikembalikan lagi kepada masyarakat yang membutuhkan di tingkat desa. Prasanjaya dan Ramantha (2013) menyatakan LPD menggali dana dari masyarakat yang mengalami surplus dan menyalurkannya kembali kepada masyarakat yang membutuhkan, terutama di daerah pedesaan. Artha (1999:1) juga mengungkapkan bahwa bagaimanapun LPD merupakan lembaga perkreditan yang operasionalnya seperti lembaga perbankan walaupun sebenarnya LPD itu bukan bank. Sehingga LPD bisa dikatakan unik, karena di satu sisi LPD berbasis komunitas desa pakraman dan berdasarkan hukum adat serta misinya tidak hanya bernuansa ekonomi tetapi juga bercorak kultural-religius, namun disisi lain pengukuran kinerja (tingkat kesehatannya) mengadopsi manajemen perbankan. Untuk dapat memenuhi tujuan dan misi LPD, sangat perlu mengetahui faktor penilaian yang mempengaruhi pertumbuhan labanya.

Biro Perekonomian dan Pembangunan Sekretariat Daerah Provinsi Bali (2012:75) dalam buku Standar Operasional Prosedur (SOP) administrasi pengelolahan LPD dimana penilaian tingkat kesehatan LPD menggunakan faktor-faktor Capital, Asset, Earning, Liquidity (CAEL). Penilaian ini mengacu pada SK Direksi BPD Bali No.0303.102.2004.2. Kemampuan faktor-faktor CAEL ini sebagai dasar untuk mengetahui pengaruh pertumbuhan laba LPD.
Selain CAEL, tidak kalah pentingnya memperhatikan non performing loan (NPL). Variabel ini sebagai indikator kredit yang menunggak melebihi 90 hari. Mengacu pada Peraturan bank Indonesia Nomor:13/3/PBI/2011, bank dinilai memiliki potensi kesulitan yang membahayakan kelangsungan usahanya apabila NPL secara neto lebih dari 5 persen dari total kredit atau total pembiayaan. Hal ini juga sangat penting diperhatikan oleh pihak LPD karena operasional LPD tidak jauh berbeda dengan bank (BPR) sehingga kelangsungan usahanya tidak terganggu.

LPD harus mampu bersaing dengan sektor perbankan yang berkembang dengan cepat. Lingkungan bisnis berkembang terus dengan iklim bisnis yang semakin kompetitif sehingga perlu memahami kunci penentu kesuksesan dan faktor yang mempengaruhi laba. Hal ini dapat menjadi faktor penentu kelangsungan hidup serta menjadi landasan fundamental bagi pembangunan berkelanjutan LPD. Tujuan penelitian adalah menguji pengaruh CAEL dan NPL terhadap pertumbuhan laba LPD di Kabupaten Badung, Provinsi Bali. Proksi dari masing-masing variabel CAEL yang digunakan adalah mengacu pada pedoman SOP administrasi LPD tahun 2012.

Lunenburg (2011) menyatakan teori penetapan tujuandalam situasi yang tepat dapat menjadi teknik yang efektif dalam memotivasi anggota dari sebuah organisasi. Selanjutya, teori ini bisa mempengaruhi cara organisasi dalam mengukur kinerjanya. Dalam penelitian, pertumbuhan laba merupakan cerminan dari kinerja LPD. Kemampuan dalam menghasilkan serta pertumbuhan laba dan juga efisiensi usaha yang dicapai LPD dapat dilihat dari pertumbuhan labanya. Pertumbuhan laba dapat berupa penurunan laba atau kenaikan laba per tahun.Kenaikan laba diharapkan dapat memenuhi semua kewajibannya dengan baik sesuai dengan peraturan serta mampu suatu LPD untuk melakukan kegiatan operasionalnya secara normal. Sehingga dapat dikatakan bahwa setiap LPD wajib memelihara dan memenuhi faktor-faktor CAEL sesuai dengan ketentuan serta faktor lain yang berkaitan dengan usaha LPD dan wajib menerapkan prinsip kehati-hatian dalam kegiatan usaha.

CAEL dan NPL sangat perlu diperhatikan untuk mendorong LPD yang sehat dan efisien.Pada unsur Capital, kinerja yang dievaluasi adalah permodalan yangdidasarkan pada kewajiban penyediaan modal minimum (KPMM) atau Capital Adequasy Ratio (CAR). KPMM atau CAR merupakan perbandingan antara modal dan aktiva tertimbang menurut resiko (ATMR). Penetapan CAR minimum LPD oleh 
Peraturan Daerah Provinsi Bali tentang LPD sebesar 8 persen. Pemenuhan minimal atau lebih jumlah CAR sesuai dengan ketentuan akan berpengaruh terhadap pertumbuhan laba LPD.

Beberapa penelitian sebelumnya terkait dengan capital diantaranya Fathoni dkk (2012) menemukan CAR berpengaruh terhadap pertumbuhan laba lembaga keuangan. Sapariyah (2012) menyatakan variabel capital yang dinyatakan dengan CAR berpengaruh positif terhadap pertumbuhan laba. Namun Pahlevie (2009), Dewi dan Sudiartha (2012), serta Setyaningsih dan Herawati (2014) menemukan CAR tidak berpengaruh signifikan terhadap pertumbuhan laba. Negara dan Sujana (2014) juga menemukan CAR tidak berpengaruh terhadap profitabilitas. Berdasarkan teori dan beberapa hasil penelitian, maka hipotesis yang diajukan:

$\mathrm{H}_{1}$ : CAR berpengaruh positif terhadap pertumbuhan laba

Kualitas aktiva LPD berkaitan dengan kelangsungan usaha LPD, hal ini dikarenakan manajemen LPD harus terus memantau perkembangan dan perubahan kualitas aktiva produktif (KAP) secara periodik baik bulanan, triwulanan atau semesteran.KAP adalah rasio perbandingan APYD (aktiva produktif yang diklasifikasikan) terhadap total aktiva produktif. Semakin kecil KAP berarti semakin efektifnya kinerja lembaga keuangan untuk menekan APYD serta memperbesar total aktiva produktif sehingga akan memperbesar pendapatan, sehingga laba yang dihasilkan semakin bertambah. Penelitian yang dilakukan oleh Pahlevie (2009), variabel KAP berpengaruh terhadap perubahan laba. Sedangkan, Ariyanti(2010) menemukan secara parsial bahwa variabel KAP tidak berpengaruh signifikan negatif pada variabel perubahan laba.PPAP (Penyisihan Penghapusan Aktiva Produktif) adalah rasio yang memperlihatkan kemampuan manajemen lembaga keuangan dalam menjaga kualitas aktiva produktifnya sehingga jumlah PPAP suatu lembaga keuangan dapat dikelola dengan baik. Semakin besar PPAP berarti semakin buruk aktiva produktifnya sehingga kemungkinan suatu lembaga keuangan dalam kondisi bermasalah semakin besar (Almilia \& Herdiningtyas, 2005). Hasil penelitianWidati (2012) menemukan PPAP tidak signifikan terhadap kinerja Perbankan/ ROA. Berdasarkan teori dan beberapa hasil penelitian, maka hipotesis yang diajukan:

$\mathrm{H}_{2}$ : KAP berpengaruh positif terhadap pertumbuhan laba

$\mathrm{H}_{3}$ : PPAP berpengaruh positif terhadap pertumbuhan laba
Unsur earning atau laba dapat ditunjukkan dari kemampuan suatu LPD dalam menghasilkan serta meningkatkan laba dan juga efisiensi usahayang dicapai. Rasio yang digunakan untuk menilai unsur earning yaitu ROA (Return on Assets)dan BOPO (Beban operasional terhadap pendapatan operasional).

Hasil penelitian(Afanasieff et al., 2002), menunjukkan bahwa BOPO berpengaruh signifikan terhadap laba. Setyaningsih dan Herawati (2014) menunjukkan bahwa BOPO secara parsial berpengaruh pada perubahan laba. Sumarno (2014) menemukan bahwa BOPO mempengaruhi secara negatif dan signifikan terhadap return saham.Thalib (2016) menyatakan variabel efisiensi (BOPO) berpengaruh dengan arah negatif terhadap profitabilitas bank. Rasio BOPO berpengaruh negatif terhadap pertumbuhan labaartinya semakin kecil BOPO semakin efisien lembaga keuangan berdasarkan jumlah dana yang berhasil dikumpulkan untuk menjalankan usaha pokoknya terutama kredit (Dewi dan Sudiartha, 2012). Sedangkan, penelitian yang dilakukan oleh Pahlevie (2009), Fathoni et al., (2012), (Ariyanti, 2010)dan Mahendra dan Rahardjo (2011) menunjukkan variabel BOPO tidak berpengaruh signifikan terhadap variabel perubahan laba. Berdasarkan teori dan beberapa hasil penelitian yang diungkapkan dalam pendahuluan dan tujuan penelitian, maka dibangun hipotesis penelitian.

$\mathrm{H}_{4}$ : BOPO berpengaruh negatif terhadap pertumbuhan laba

Komponen penting dari perencanaan keuangan adalah peramalan profitabilitas. Tingkat efisiensi suatu lembaga keuangan bisa dihitung melalui profitabilitas (Sinha and Dutta, 2011). ROAdigunakan untuk melihat keefektifan lembaga keuangan dalam menghasilkan keuntungan dengan memanfaatkan aktiva yang dimiliki. Rasio ini dianggap sebagai indikator seberapa efisien suatu lembaga menggunakan asetnya untuk menghasilkan laba bersih sebelum kewajiban kontraktual harus dibayar (Prakash, 2012). Meningkatnya ROA menandakan besarnya pengembalian yang diperoleh oleh suatu lembaga keuangan. Suatu lembaga keuangan yang mempunyai ROA yang tinggi, maka akan semakin tinggi tingkat laba yang dicapai lembaga keuangan tersebut, kemungkinan suatu lembaga keuangan dalam kondisi bermasalah semakin kecil dan semakin lebih baik pula posisi lembaga keuangan tersebut dari segi penggunaan aset sehingga yang nantinya berpengaruh dalam pertumbuhan laba di masa depan (Dendawijaya, 2000). ROA berpengaruh terhadap pertumbuhan laba lembaga keuangan, berarti 
perusahaan yang mampu menghasilkan earnings yang lebih besar cenderung memiliki pertumbuhan laba lembaga keuangan yang lebih tinggi (Fathoni et al., 2012).Wijaya (2013) menemukan bahwa ROA berpengaruh positif signifikan terhadap pertumbuhan laba, berdasarkan beberapa hasil penelitian yang diungkapkan dalam pendahuluan dan tujuan penelitian, maka peneliti mengajukan hipotesis penelitian

$\mathrm{H}_{5}$ : ROA berpengaruh positif terhadap pertumbuhan laba

Hanafi (2009:241) mengungkapkan bahwa risiko likuiditas terjadi akibat perusahaan mengalami kesulitan atau tidak mampu memenuhi kewajiban jangka pendeknya. Penilaian likuiditas pada unsur ini didasarkan pada kemampuan LPD dalam membayar hutang-hutangnya terutama simpanan tabungan dan deposito pada saat jatuh tempo dan dapat merealisasikan semua permohonan pinjaman yang layak. Liquid Asset to Current Liabilities Ratio (LACLR) digunakan untuk mengukur kemampuan LPD dalam memenuhi kewajiban keuangan yang harus segera dipenuhi atau saat ditagih.Semakin besar rasio ini semakin baik karena kemampuan LPD dalam membayar kewajiban lancar yang dijamin dengan alat likuid yang dimiliki LPD. Sehingga, hipotesis yang diajukan dalam penelitian:

$\mathrm{H}_{6}$ : LACLR berpengaruh positif terhadap Pertumbuhan Laba

LDR (Loan to Deposit Ratio) adalah ukuran likuiditas untuk mengetahui besarnya dana bersumber dari pihak ketiga yang ditempatkan dalam bentuk kredit. LDR yang meningkat berarti semakin besar dana yang disalurkan dan akan meningkatkan pendapatan lembaga keuangan dalam kondisi normal. Sehingga semakin besar LDR lembaga keuangan maka semakin besar pula perubahan laba lembaga keuangan Ariyanti, (2010). Angbazo (1997) menunjukkan LDR berpengaruh positif terhadap laba dan Afanasief et al., (2002) menunjukkan bahwa LDR berpengaruh signifikan terhadap laba.Penelitian Pahlevie (2009) serta Setyaningsih dan Herawati (2014) menunjukkan pula secara parsial variabel LDRberpengaruh signifikan positif terhadap variabel perubahan laba. Sumarno (2014) menemukan bahwa LDR mempengaruhi secara positif dan signifikan terhadap return saham. Namun penelitian Sapariyah (2012) serta Dewi dan Sudiartha (2012) menemukan bahwa LDR berpengaruh tidak signifikan terhadap pertumbuhan laba. Sejalan dengan Fathoni dkk. (2012) menemukan bahwa LDR tidak berpengaruh terhadap pertumbuhan laba lembaga keuangan. Berdasarkan teori dan beberapa hasil penelitian yang diungkapkan dalam pendahuluan dan tujuan penelitian, maka dalam penelitian ini hipotesis yang diajukan:

$\mathrm{H}_{7}$ : LDR berpengaruh positif terhadap Pertumbuhan Laba

NPL (Non Performing Loan) merupakan proksi yang menunjukkan kemampuan manajemen bank dalam mengelola kredit bermasalah yang diberikan oleh bank (Jha dan Hui, 2012). Tingkat NPL semakin meningkat berarti semakin buruk kualitas kredit bank yang menyebabkan kredit bermasalah semakin besar dan berdampak kepada kerugian bagi perusahaan (Sastrosuwio, 2012). Semakin rendah NPL maka semakin tinggi laba yang akan dihasilkan oleh LPD, sebaliknya semakin tinggi NPL maka laba yang dihasilkan dari kredit semakin rendah. Hasil penelitian Nawaz et al., (2012) dan Kolapo, et al., (2012) menemukan bahwa NPL memiliki pengaruh negatif pada profitabilitas. Joseph et al.,(2012) mendukung penelitian bahwa NPL memi liki pengaruh negatifpada ROA. SedangkanMahardian (2008) mengungkapkanIHYGGHJ. bahwa NPL memiliki pengaruh tidak signifikan terhadap ROA dengan arah negatif, yang mana selama periode penelitian, fungsi intermediasi bank tidak berjalan dengan baik. Aini (2013) menemukan bahwa NPL berpengaruh tidak signifikan dengan arah positif terhadap perubahan laba.Berdasarkan teori dan beberapa hasil penelitian, maka hipotesis yang diajukan:

$\mathrm{H}_{8}$ : NPL berpengaruh negatif terhadap pertumbuhan laba

\section{METODE PENELITIAN}

Penelitian dilakukan di LPD Kabupaten Badung melalui Lembaga Pemberdayaan Lembaga Perkreditan Desa (LPLPD) dan secara langsung ke beberapa LPD di Kabupaten Badung. LPD di Kabupaten Badung dipilih karena memiliki aset terbesar dibandingkan LPD-LPD yang berada di Kabupaten/Kota lain di Bali yakni sebesar Rp 4.673.020.671.000 (LPLPD Provinsi Bali, 2015). Dengan tingkat aset serta kepercayaan masyarakat atau nasabah yang besar, pada umumnya juga memiliki resiko yang besar pula jika salah mengelolanya.

Penelitian menggunakan jenis data sekunder yaitu berupa laporan keuangan tahunan dan atau rasio CAEL dan NPL LPD dari tahun 2013-2015 melalui LPLPD dan beberapa langsung di LPD Kabupaten Badung. Jumlah LPD di Kabupaten 
Badung sebanyak 122 LPD (LPLPD Kabupaten Badung, 2016). Penentuan jumlah sampel dilakukan dengan rumus Slovin, sehingga diperoleh sampel sebanyak 53 LPD. Teknik pengambilan sampelnya adalah simple random sampling yang dilakukan dengan cara undian.

Variabel bebas penelitian adalah CAEL dan NPL. Sedangkan variabel terikatnya yaitu pertumbuhan laba. CAR merupakan rasio yang menunjukkan seberapa jauh seluruh aktiva lembaga keuangan yang mengandung risiko (kredit, penyertaan, surat berharga, tagihan pada lembaga keuangan lain) ikut dibiayai dari dana modal sendiri lembaga keuangan disamping memperoleh danadana dari sumber-sumber diluar lembaga keuangan, seperti dana masyarakat, pinjaman (utang) dan lainlain (Dendawijaya,2000). ATMR dihitung dengan memberikan bobot masing-masing aktiva yang besar risiko didasarkan pada golongan nasabah, pinjaman serta sifat agunan. ATMR yang dimaksud terdiri atas kas, tabungan, deposito, giro di bank.

Komponen modal inti terdiri modal di setor, modal donasi, cadangan umum, cadangan tujuan, laba tahun lalu, rugi tahun lalu, laba tahun berjalan dan rugi tahun berjalan. Komponen dari modal pelengkap antara laincadangan PPAP, modal pinjaman dan akumulasi penyusutan.

KAP merupakan rasio perhitungan APYD (aktiva produktif yang diklasifikasikan dengan total aktiva produktif. Komponen APYD dimuat dalam pinjaman yang diberikan oleh LPD dengan dengan kriteria lancar, kurang lancar, diragukan, dan macet. Total aktiva produktif terdiri dari tabungan, deposito, giro dibank serta pinjaman yang diberikan.

PPAP menunjukkan kemampuan manajemen lembaga keuangan dalam menjaga kualitas aktiva produktif sehingga jumlah PPAP dapat dikelola dengan baik. Variabel PPAP merupakan perbandingan antara cadangan PPAP yang telah dibuat dengan PPAP yang wajib dibentuk.

Rasio BOPO adalah rasio efisiensi usaha yang membandingkan antara biaya operasional terhadap pendapatan operasional. ROA merupakan perbandingan antara laba tahun berjalan dengan total aset, rasio ini sebagai pengukur kemampuan LPD untuk memperoleh laba dari aset yang digunakan dalam operasional.

Liquidity diukur dengan LACLR dan LDR. LACLR adalah perbandingan antara aset likuid dengan hutang lancar. LDR merupakan perbandingan antara jumlah kredit dengan dana yang dimiliki oleh suatu lembaga keuangan (Dendawijaya, 2000). Kredit (Pinjaman yang diberikan) merupakan total kredit yang diberikan kepada pihak ketiga yaitu kas dan dana dibank (tidak termasuk antar lembaga keuangan).

Rasio NPL adalah perbandingan kredit bermasalah dengan total kredit. Pertumbuhan laba yaitu dengan cara laba periode sekarang dikurangi dengan laba periode sebelumnya kemudian dibagi dengan laba pada periode sebelumnya.

Analisis data yang digunakan untuk menguji pengaruh CAEL dan NPL terhadap pertumbuhan laba menggunakan analisis regresi linier berganda (multiple regression model), dengan pengujian asumsi klasik. Bentuk umum persamaan regresi bergandanya, sebagai berikut :

$$
\begin{aligned}
\mathrm{Y}= & \alpha+\beta_{1} \mathrm{CAR}_{1}+\beta_{2} \mathrm{KAP}_{2}+\beta_{3} \mathrm{PPAP}_{3}+\beta_{4} \mathrm{BOPO}_{4} \\
& +\beta_{5} \mathrm{ROA}_{5}+\beta_{6} \mathrm{XLACLR}_{6}+\beta_{7} \mathrm{LDR}_{7}+\beta_{8} \mathrm{NPL}_{8} \\
& +\varepsilon \ldots \ldots \ldots \ldots \ldots \ldots \ldots \ldots \ldots \ldots \ldots \ldots \ldots \ldots \ldots \ldots \ldots \ldots \ldots \ldots \ldots \ldots \ldots \ldots \ldots \ldots \ldots \ldots \ldots \ldots \ldots \ldots \ldots \ldots \ldots \ldots
\end{aligned}
$$

\section{Keterangan:}

$\mathrm{Y}=$ pertumbuhan laba

$\beta=$ koefisien regresi masing-masing variabel

$\alpha=$ konstanta

$\varepsilon=$ error

\section{HASIL DAN PEMBAHASAN}

Uji asumsi klasik dilakukan sebagai persyaratan penggunaan model regresi linier berganda. Hasilnya menunjukkan bahwa model layak dan telah lolos semua uji yang meliputi uji normalitas, multikolinearitas, heteroskedastisitas, dan autokorelasi. Hasil persamaan regresi ditunjukkan pada Tabel 1. Berdasarkan Tabel 1 dapat disusun persamaan regresi linier berganda.

$\mathrm{Y}=50,626-0,178 \mathrm{CAR}-0,146 \mathrm{KAP}+0.010 \mathrm{PPAP}$

- 0,279BOPO - 0,011ROA - 0,211LACLR -

$0,071 \mathrm{LDR}-0,029 \mathrm{NPL}+\varepsilon$ .2

Berdasarkan persamaan regresi linier berganda dapat diketahui bahwa nilai konstanta sebesar 50,626 berarti, jika nilai CAR, KAP, PPAP, BOPO, ROA, LACLR, LDR dan NPL sama dengan nol maka nilai pertumbuhan laba adalah sebesar 50,626. Koefisien variabel CAR sebesar -0,178 hal ini menunjukkan hasil yang negatif berarti kenaikan satu persen CAR akan menyebabkan penurunan laba sebesar -0,178. Koefisien variabel KAP sebesar $-0,146$ hal ini menunjukkan hasil yang negatif berarti kenaikan satu persen KAP akan menyebabkan penurunan laba sebesar -0,146. Koefisien variabel PPAP sebesar 0,010 hal ini menunjukkan hasil yang positif berarti kenaikan satu persen PPAP akan menyebabkan peningkatan laba sebesar 0,010 . Koefisien variabel 
Tabel 1.

Hasil Regresi Linier Berganda

\begin{tabular}{|c|c|c|c|c|c|}
\hline \multirow[t]{2}{*}{ Variabel } & \multicolumn{2}{|c|}{ Unstandardized Coefficients } & \multirow{2}{*}{$\begin{array}{c}\text { Standardized } \\
\text { Coefficients } \\
\text { Beta }\end{array}$} & \multirow[t]{2}{*}{$\mathbf{t}$} & \multirow[t]{2}{*}{ Sig. } \\
\hline & B & Std. Error & & & \\
\hline (Constant) & 50,626 & 15,513 & & 3,263 & 0,001 \\
\hline CAR & $-0,178$ & 0,180 & $-0,131$ & $-0,988$ & 0,325 \\
\hline KAP & $-0,146$ & 0,114 & $-0,133$ & $-1,286$ & 0,200 \\
\hline PPAP & 0,010 & 0,007 & 0,139 & 1,406 & 0,162 \\
\hline $\mathrm{BOPO}$ & $-0,279$ & 0,125 & $-0,309$ & $-2,228$ & 0,027 \\
\hline ROA & $-0,011$ & 0,166 & $-0,007$ & $-0,063$ & 0,949 \\
\hline LACLR & $-0,211$ & 0,121 & $-0,245$ & $-1,753$ & 0,082 \\
\hline LDR & $-0,071$ & 0,121 & $-0,074$ & $-0,590$ & 0,556 \\
\hline NPL & $-0,029$ & 0,120 & $-0,025$ & $-0,246$ & 0,806 \\
\hline
\end{tabular}

Sumber:Data diolah, 2016

BOPO sebesar -0,279 hal ini menunjukkan hasil yang negatif berarti kenaikan satu persen BOPO akan menyebabkan penurunan laba sebesar-0,279. Koefisien variabel ROA sebesar $-0,011$ hal ini menunjukkan hasil yang negatif berarti kenaikan satu persen ROA akan menyebabkan penurunan laba sebesar -0,011. Koefisien variabel LACLR sebesar $-0,211$ hal ini menunjukkan hasil yang negatif berarti kenaikan satu persen LACLR akan menyebabkan penurunan laba sebesar $-0,211$. Koefisien variabel
LDR sebesar -0,071 hal ini menunjukkan hasil yang negatif berarti kenaikan satu persen LDRakan menyebabkan penurunan laba sebesar -0,071. Begitu pula NPL, Koefisien variabel NPL sebesar $-0,029$ hal ini menunjukkan hasil yang negatif berarti kenaikan satu persen NPLakan menyebabkan penurunan laba sebesar -0,029. Kesemua perubahan pada setiap variabel independen ini berlaku dengan asumsi bahwa semua variabel lain tidak berubah.

Tabel 2.

Hasil Uji ANOVA

\begin{tabular}{lrrrrr}
\hline \multicolumn{1}{c}{ Model } & Sum of Squares & Df & Mean Square & \multicolumn{1}{c}{ F } & \multicolumn{1}{c}{ Sig. } \\
\hline Regression & 1327,785 & 8 & 165,973 & 2,503 & $0,014^{\text {b }}$ \\
Residual & 9944,789 & 150 & 66,299 & & \\
Total & 11272,574 & 158 & & & \\
\hline
\end{tabular}

Sumber:Data diolah, 2016

Uji kelayakan model digunakan untuk menguji apakah model yang diperoleh dari penelitian ini layak atau tidak untuk melakukan fungsi prediksi. Berdasarkan hasil uji ANOVA pada Tabel 2, diperoleh nilai Sig (F-statistic) sebesar 0,014. Dengan nilai Sig F sebesar 0,014 lebih kecil dari dengan menggunakan alpha 0,05 (5\%), maka dapat disimpulkan bahwa model layak digunakan dalam kapasitasnya sebagai fungsi prediksi. Selanjutnya koefisien determinasi digunakan untuk menentukan besarnya kontribusi pengaruh variabel independen secara bersama-sama terhadap variabel dependen dan hasilnya ditunjukkan pada Tabel 3.

Tabel 3.

Hasil Uji Koefisien Determinasi

\begin{tabular}{ccccc}
\hline Model & R & R Square & Adjusted R Square & $\begin{array}{c}\text { Std. Error of the } \\
\text { Estimate }\end{array}$ \\
\hline 1 & $0,343^{\mathrm{a}}$ & 0,118 & 0,071 & 8,14239 \\
\hline
\end{tabular}

Sumber:Data diolah, 2016

Berdasarkan Tabel 3 terlihat bahwa hasil uji koefisien determinasi menunjukkan besarnya adjusted $\mathrm{R}^{2}$ adalah 0,071 , hal ini berarti 7,1 persen variasi pertumbuhan laba dapat dijelaskan oleh variasi dari ke delapan variabel bebas CAR, KAP, PPAP,
BOPO, ROA, LACLR, LDR dan NPL. Sedangkan sisanya 92,9 persen dipengaruhi oleh variabel lain.

Uji-t dilakukan untuk mengetahui signifikansi pengaruh masing-masing variabel CAR, KAP, PPAP, BOPO, ROA, LACLR LDR dan NPL, terhadap 
pertumbuhan laba. Mengacu pada Tabel 1 terlihat nilai Sig untuk variabel BOPO menunjukkan pengaruh yang signifikan pada variabel pertumbuhan laba. Hipotesis BOPO berpengaruh negatif terhadap pertumbuhan laba adalah diterima. Hal ini dapat dilihat dari angka signifikan BOPO sebesar 0,027 kurang dari signifikansi 0,05 . Sedangkan variabel CAR, KAP, PPAP, ROA, LACLR, LDR dan NPL tidak berpengaruh secara signifikan pada variabel pertumbuhan laba dengan taraf signifikan 0,05 sehingga hipotesisnya tidak diterima.

CAR tidak berpengaruh secara signifikan pada pertumbuhan laba LPD Kabupaten Badung periode tahun 2013-2015. Hal ini mengindikasikan semakin rendah rasio CAR, maka berdampak pada turunnya pertumbuhan laba LPD, artinya jika modal LPD semakin kecil maka kemungkinan LPD dalam kondisi bermasalah semakin besar. Pemenuhan kecukupan modal mempunyai tujuan untuk menyerap kerugiankerugian lembaga keuangan yang terjadi dalam melakukan penanaman dana atau penurunan aktiva di kemudian hari. Semakin besar modal yang dimiliki oleh suatu LPD akan meningkatkan rasio kecukupan modalnya, sebaliknya bila modal LPD terus menerus terkikis oleh kerugian yang dialaminya, maka rasio kecukupan modalnya akan turun. Penurunan jumlah modal LPD akan berdampak pada berkurangnya fungsi dari modal LPD seperti penyanggah pengembalian dana kreditur dalam bentuk tabungan dan deposito, menjamin kelangsungan operasional dan pemenuhan persyaratan pemenuhan modal minimal.

Modal bank memiliki beberapa fungsi utama, salah satunya adalah melindungi para penyimpan uang (deposan) dari kerugian yang timbul (Abdullah dan Tantri, 2014:156). Modal LPD digunakan untuk menjaga kepercayaan masyarakat. Kepercayaan masyarakat amat penting artinya bagi LPD, karena LPD akan menghimpun dana untuk keperluan operasional, fungsi intermidiasi keuangan, menjaga posisi likuiditas dan investasi dalam aktiva tetap. Peraturan Gubernur Bali Nomor 11 Tahun 2013 tentang LPD Pasal 3 (5) diungkap bahwa batas maksimum pengadaan aktiva tetap dan inventaris adalah 50\% dari modal. Jumlah modal LPD belum mampu memberikan kontribusi berarti terhadap pertumbuhan laba, hal ini kemungkinan unsur modal LPD sebagian besar ditempatkan dalam aktiva non produktif. Hasil penelitian ini konsisten dengan penelitian yang dilakukan oleh Pahlevie (2009) menemukan bahwa variabel CAR tidak berpengaruh signifikan terhadap perubahan laba. Juga hasil penelitian ini mendukung penelitian (Respati dan Eri, 2008) dan Prasanjaya dan Ramantha (2013) CAR tidak berpengaruh signifikan terhadap laba usaha. Begitupula hasil penelitian Hutagalung dkk. (2013), Zulfikar (2014) dan Ariani dan Ardiana (2015), variabel CAR berpengaruh tidak signifikan terhadap ROA.

KAP tidak berpengaruh signifikan pada variabel pertumbuhan laba. Semakin besar aktiva produktif bermasalah seperti tabungan, deposito, giro, maka semakin besarmaka semakin besaruntuk membentuk PPAP.Jumlah pembentukan PPAP ini merupakan beban bagi lembaga keuangan. Hal ini juga diduga bahwa kualitas aktiva produktif LPD belum efektif, terutama kinerja manajemen LPD untuk menekan aktiva produktif yang diambil alih. Aktiva produktif yang diambil alih yang semakin besar bisa mengakibatkan pandapatan dari aktiva produktif semakin menurun dan pertumbuhan labanya menurun sehingga berdampak pada keberlanjutan usaha LPD. Hasil penelitian variabel KAPini konsisten dengan hasil penelitian Ariyanti (2010) menemukan bahwa secara parsial variabel kualitas aktiva produktif berpengaruh negatif pada variabel perubahan laba. Begitu pula hasil penelitian Mahendra dan Rahardjo (2011) yakni KAP tidak berpengaruh pada perubahan laba serta Andayani dkk. (2015) menemukan bahwa KAP tidak berpengaruh signifikan pertumbuhan laba.

PPAP tidak berpengaruh berarti positif terhadap pertumbuhan laba. Hal ini membuktikan manajemen LPD Kabupaten Badung periode penelitian ini belum maksimal mengelola PPAP-nya. PPAP yang tinggi mencerminkan kualitas aktiva produktif suatu lembaga keuangan termasuk LPD adalah kurang baik. Semakin besar KAP bermasalah maka PPAP yang harus atau wajib dibentuk semakin besar pula. Semakin besar PPAP maka semakin buruk aktiva produktifnya sehingga indikasi suatu lembaga keuangan dalam kondisi bermasalah semakin besar (Almilia dan Herdiningtyas, 2005). Hasil penelitian ini mendukung hasil penelitian Respati (2008) PPAP tidak berpengaruh terhadap laba usaha bank umum swasta nasional secara signifikan. Begitu pula, Widati (2013) menemukan bahwa PPAP tidak signifikan terhadap ROA.

BOPO LPD di Kabupaten Badung periode penelitian ini berpengaruh signifikan negatif terhadap pertumbuhan laba. Pada umumnya unsur biaya operasional yang besar bersumber dari biaya bunga. Biaya bunga ditentukan berdasarkan perhitungan biaya dana pihak ketiga, dan pendapatan bunga 
sebagian besar diperoleh dari pendapatan bunga kredit. Sehingga ini mengindikasikan bahwa semakin besar rasio BOPO pada LPD maka akan berdampak pada turunnya pertumbuhan laba LPD artinya semakin tinggi biaya operasional terhadap pendapatan operasional, maka semakin boros biaya operasional yang dikeluarkan oleh LPD yang bersangkutan. Sebaliknya semakin rendah rasio BOPO mencerminkan semakin efisien LPD dalam operasionalnya terutama pinjaman yang diberikan berdasarkan jumlah dana yang diterima dan dipercayakan oleh nasabah penabung dan deposan. Hasil penelitian ini konsisten dengan teori penetapan tujuan, dimana terdapat dimensi partisipasi tujuan dalam pencapaian tujuan perusahaan.Semakin rendah tingkat BOPO LPD maka semakin efisien LPD tersebut, sehingga sumberdaya manusia turut berpartisipasi pencapaian tujuan LPD. Hal ini mendukung penelitianRespati (2008), BOPO memiliki pengaruh signifikan terhadap laba usaha Bank Umum Swasta Nasional. Mahardian (2008), Hutagalung dkk. (2013), Raharjo dkk. (2014), dan Dewi dkk. (2015) menyatakan BOPO berpengaruh negatif terhadap ROA. Sumarno (2014) menemukan bahwa BOPO mempengaruhi secara negatif terhadap return saham bank. Ariani dan Ardiana (2015) tingkat efisiensi (BOPO) berpengaruh negatif pada profitabilitas. Dewi dan Budiasih (2016) BOPO berpengaruh negatif pada profitabilitas. Serta Aini (2013) BOPO berpengaruh negatif signifikan terhadap perubahan laba, dan Thalib (2016) mengungkapkan BOP berpengaruh negatif terhadap profitabilitas bank.

Hasil penelitian menunjukkan ROA tidak secara signifikan berpengaruh terhadap pertumbuhan laba. ROA yang rendah menunjukkan LPD dalam meningkatkan laba operasi dan prospek masa depan belum efisien. Artinya semakin efisien pengelolaan aset suatu usaha LPD, berarti bahwa sumber daya yang sedikit mampu dikelola dengan baik sehingga mampu menghasilkan manfaat yang sebesarbesarnya. ROA yang tinggi menunjukkan bahwa LPD tersebut memiliki kemampuan yang besar dalam meningkatkan laba operasi dan prospek masa depan.Sebaliknya, semakin rendah tingkat laba maka semakin rendah pula ROA LPD. ROA dapat digunakan untuk mengukur efektifitas LPD penggunaan sumber daya yang ada dari hasil pengembaliannya. Dikaitkan dengan hasil empiris ini, ROA tidak berpengaruh secara berarti pada pertumbuhan laba, hal ini diduga masih banyak terdapat kredit bermasalah.
LACLR tidak berpengaruh signifikan pada petumbuhan laba. Hal ini dapat diartikan bahwa semakin likuid sebuah LPD untuk memenuhi kewajibannya pertumbuhan labanya akan menurun, dikarenakan banyak aktiva produktif yang tidak produktif (idlecash). Rasio LACLR digunakan untuk mengukur kemampuan LPD dalam memenuhi kewajiban keuangan yang harus segera dipenuhi atau kemampuan LPD untuk memenuhi kewajiban keuangan pada saat ditagih. Semakin besar rasio ini semakin baik karena berkaitan dengan kepercayaan kepada masyarakat, nasabah dan pemerintah semakin baik terutama kemampuan LPD dalam membayar kewajiban lancar yang dijamin dengan alat likuid yang dimiliki LPD, namun idle cash yang terlalu besar akan berdampak pada perolehan pendapatan yang semakin kecil. Penelitian ini konsisten hasil penelitian Respati (2008) bahwa CBSTD tidak signifikan berpengaruh terhadap laba usaha bank umum swasta nasional.

LDR tidak secara signifikan berpengaruh terhadap pertumbuhan laba. Peningkatan jumlah kredit yang disalurkan ke nasabah, semestinya akan diikuti juga dengan peningkatan pendapatan dan sekaligus kemampuan LPD dalam menghasilkan laba. Salah satu fungsi LPD adalah sebagai lembaga intermediasi yang menghubungkan pihak pemilik dana lebih kepada pihak yang memerlukan dana khususnya di desa adat. LPD menerima simpanan masyarakat dalam bentuk tabungan dan deposito dan menyalurkan kembali kepada warga desa adat dalam bentuk kredit. Namun hasil bukti empiris menunjukkan bahwa LDR berpengaruh negatif terhadap pertumbuhan laba, berarti LPD masih belum mampu menjalankan fungsi intermediasinya. Hal ini mengidentifikasikan LPD belum maksimal menyalurkan fasilitas kredit dan menempatan dana pihak ketiga (DPK) pada bank atau lembaga keuangan lainnya. LPD dalam penyaluran kredit ke masyarakatbisa sudah maksimal, namun tidak dikuti peningkatan laba secara berarti. Hal ini ada kemungkinan kredit yang disalurkannya banyak bermasalah sehingga pendapatan atas bunga kredit yang dibayar dari debitur tidak sesuai dengan perjanjian, serta fasilitas kredit yang disalurkan ke beberapa nasabah debitur melebihi batas maksimal pemberian kredit (BMPK) dan akhirnya debitur tersebut tidak memenuhi kewajibannya.Oleh karenanya, manajemen LPD harus memperhatikan potensi resiko ini supaya LPD bisa tetap membayar biaya DPK termasuk penarikannya dan merupakan 
indikasi sebagai faktor menambah kerugian LPD. Hasil penelitian ini konsisten dengan penelitian yang dilakukan oleh Aini (2013) LDR berpengaruh tidak signifikan terhadap perubahan laba. Hasil penelitian ini juga mendukung hasil penelitian Mintarti (2009) LDR tidak berpengaruh terhadap ROA bank-bank umum swasta nasional take over. Serta Hutagalung dkk. (2013) dan Zulfikar (2014) variable LDR berpengaruh tidak signifikan terhadap ROA.

NPL berpengaruh negatif terhadap pertumbuhan laba LPD. NPL LPD berpengaruh terhadap penurunan laba LPD, namun penurunannya tidak secara berarti.Hal ini terindentifikasi bahwa LPD memiliki kredit yang bermasalah yang cukup banyak, namun tidak banyak dalam kredit katagori macet, diduga bahwa pihak manajemen LPD mengambil kebijakan restrukturisasi kredit yang terkatagori macet, sehingga ada pendapatan administrasi serta ada pengakuan bunga kredit. Pihak debitur akan berupaya membayar kewajibannya walaupun jumlah pembayarannya tidak sesuai dengan jumlah yang seharusnya dilunasi setiap periode. Pengurus LPD jugaakan berupaya untuk menagih pinjaman yang diberikan termasuk kewajiban lain kepada debitur, sesuai dengan awig-awig atau pararem masingmasing desa pakraman yang berlaku di tempat desa pakraman LPD. Pada umumnya pihak debitur yang bermasalah diumumkan pada rapat/paruman banjar atau desa. Dengan adanya saksi demikian pihak debitur akan merasa malu dan akan berusaha untuk membayar kewajibannya. Disamping itu umumnya pihak debitur akan berupaya juga untuk melunasi kewajibannya karena dia percaya sesuai dengan keyakinannya yaitu hukum karmaphala (Sujana, 2014:240). Hasil penelitian ini mendukung penelitian Mahardian (2008) variabel NPL terdapat pengaruh tidak signifikan negatif terhadap ROA, yang mana selama periode penelitian, fungsi intermediasi bank tidak berjalan dengan baik. Respati (2008) NPL tidak signifikan berpengaruh terhadap laba usaha pada bank umum swasta nasional. Nur Aini (2013) NPL tidak signifikan terhadap perubahan laba. Azeem dan Amara, (2014) mengungkapkan bahwa dampak NPL pada profitabilitas adalah negatif. Dewi dkk. (2015) secara parsial diketahui bahwa NPL berpengaruh signifikan negatif terhadap ROA. Haneef et al., (2012) menyimpulkan bahwa meningkatnya NPL karena kurangnya manajemen risiko yang mempengaruhi profitabilitas bank. Zulfikar (2014) NPL secara statistik tidak berpengaruh secara signifikan terhadap ROA.

\section{SIMPULAN}

Penelitian ini menyimpulkan bahwa variabel BOPO dapat menjadi prediktor pada pertumbuhan laba serta memiliki hubungan yang tidak searah dengan pertumbuhan laba. Jika LPD memiliki BOPO yang rendah maka dapat sebagai indikasi operasionalnya akan cenderung efisien serta semakin meningkat labanya, sebaliknya semakin tinggi BOPO maka akan cenderung tidak efisien operasional serta labanya semakin tur8un.Sedangkan variabel CAR, KAP, PPAP, ROA, LACLR, LDR dan NPL tidak berpengaruh signifikan terhadap pertumbuhan laba LPD di Kabupaten Badung periode penelitian 20132015.

Sampel penelitian hanya LPD yang berada di Kabupaten Badung yang memiliki aset terbesar di antara LPD yang ada di kabupaten lain dan kota di Bali, sehingga belum mampu mempresentasikan semua LPD yang ada di Bali. Disarankan untuk peneliti berikutnya juga mempergunakan sampel LPD yang ada di Kabupaten lain dan Kota yang ada di Bali. Serta banyak variabel penelitian ini tidak berpengaruh secara signifikan, maka juga disarankan peneliti selanjutkan menggunakan metode kualitatif (wawancara) untuk mengetahui faktor-faktor yang mampu mempengaruhi pertumbuhan laba di LPD.

Implikasi pada manajemen LPD dalam pengelola usahanya tetap memperhatikan prinsip kehatianhatian,walaupun merupakan suatu hal yang sulit dihindari terjadinya kredit macet. Pernyataan ini didukung data bahwa terdapat beberapa LPD memiliki rasio NPL di atas 5 persen.Disamping itu, manajemen LPD tetap memperhatikan prinsip kehatian-hatian tersebut supaya keberlangsungan usaha LPD tetap berlanjut sehingga dapat memberikan manfaat bagi warga desa pakraman dan atau desa pakraman.

\section{REFERENSI}

Afanasieff, T. S., Maria, P., \& Lhacer, V. (2002). The Determinants of Bank Interest Spread in Brazil. Money Affairs, 15(2), 183-207.

Aini, N. (2013). Pengaruh CAR, NIM, LDR, BOPO dan Kualitas Aktiva Produktif Terhadap Perubahan Laba (Studi Empiris Pada Perusahaan Perbankan yang Terdaftar di BEI) Tahun 2009-2011. Dinamika Akuntansi, Keuangan Dan Perbankan, 2(1), 14-25. https://doi.org/ISSN/ : 1979-4878 
Almilia, L. S., \& Herdiningtyas, W. (2005). Bermasalah Pada Lembaga Perbankan Perioda 2000-2002. Jurnal Akuntansi Dan Keuangan, 7(2), 1-27. Andayani, P. N., Yuniarta, G. A., \& Sujana, E. (2015). Pengaruh Kecukupan Modal, Kualitas Aktiva Produktif, Rentabilitas, dan Likuiditas Terhadap Pertumbuhan Laba (Studi Kasus pada Lembaga Perkreditan Desa Kabupaten Buleleng). EJournal S1 AK Universitas Pendidikan Ganesha Jurusan Akuntansi Program S1, 3(1), 1-12.

Angbazo, L. (1997). Commercial Bank Net Interest Margins, Default Risk, Interest Risk, and OffBallance Sheet Banking. Journal of Banking and Finance, 21, 55-87.

Ariani, M. W., \& Ardiana, P. A. (2015). Pengaruh Kecukupan Modal, Tingkat Efisiensi, Risiko Kredit, dan Likuiditas Pada Profitabilitas LPD Kabupaten Badung. E-Jurnal Akuntansi Universitas Udayana, 13(1), 259-275.

Ariyanti, L. E. (2010). Analisis Pengaruh CAR, NIM, LDR, NPL, BOPO, ROA dan Kualitas Aktiva Produktif Terhadap Perubahan Laba Pada Bank Umum di Indonesia. Tesis, 102.

Azeem, A., \& Amara. (2014). Impact of Profitability on Quantum of Non-Performing Loans. International Journal of Multidisciplinary Consortium, 1(June), 1-14.

Dewi, L. E., Herawati, N. T., \& Sulindawati, L. G. E. (2015). Analisis Pengaruh NIM, BOPO, LDR, dan NPL Terhadap Profitabilitas (Studi Kasus Pada Bank Umum Swasta Nasional yang Terdaftar Pada Bursa Efek Indonesia Periode 2009-2013 ). E-Journal S1 AK Universitas Pendidikan Ganesha Jurusan Akuntansi Program S1, 3(1).

Dewi, N. P. E. N., \& Budiasih, I. G. A. N. (2016). Kualitas Kredit Sebagai Pemoderasi Pengaruh Tingkat Penyaluran Kredit dan BOPO Pada Profitabilitas. E-Jurnal Akuntansi Universitas Udayana, 15(1), 784-798.

Dewi, S., \& Sudiartha, G. M. (2012). Pengaruh Rasio CAEL Terhadap Kinerja Keuangan Bank Yang Terdaftar di PT. BEI, (10), 159-175.

Fathoni, M. I., Sasongko, N., \& Setyawan, A. A. (2012). Pengaruh tingkat kesehatan bank terhadap pertumbuhan laba masa mendatang pada perusahaan sektor perbankan. Jurnal Akuntansi, 13(1), 15-25.

Haneef, S., Riaz, T., Ramzan, M., Rana, M. A., \& Karim, Y. (2012). Impact of Risk Management on Non-Performing Loans and Profitability of Banking Sector of Pakistan Hailey College of Commerce University of the Punjab Hafiz Muhammad Ishaq Federal Urdu University of Arts, Science and Technology. International Journal of Business and Social Science, 3(7), 307-315.

Hutagalung, E. N., Djumahir, \& Ratnawati, K. (2013). Analisa Rasio Keuangan terhadap Kinerja Bank Umum di Indonesia. Universitas Brawijaya Malang Fakultas Ekonomi Dan Bisnis, 11(165), 122-130.

Joseph, M. T., Edson, G., Manuere, F., Clifford, M., Michael, K., \& Kamoyo, M. (2012). Non Performing loans in Commercial Banks/ : A case of CBZ Bank Limited In Zimbabwe. Interdiscriplinary Journal of Contemporary Research in Business, 4. No 7(1996), 467-488.

Kolapo, T. F., Ayeni, R. K., \& OKE, M. O. (2012). Credit Risk dnd Commercial Banks' Performance In Nigeria: A Panel Model Approach. Australian Journal of Business and Management Research, 2(2), 31-38.

Lunenburg, F. C. (2011). Goal-Setting Theory of Motivation. International Journal of Management, Business, and Administration, 15(1), 1-6. Retrieved from http:// www.nationalforum.com/Electronic Journal Volumes/Lunenburg, Fred C. Goal-Setting Theoryof Motivation IJMBA V15 N1 2011.pdf Made Sudarma. (2013). Revealing the Agency Cost, Management Behavior in the Practice Inof Tri Hita Karana Culture (A Study At LPD Of Pakraman InVillage In Denpasar Bali). IOSR Journal of Business and Management (IOSR$J B M), 10(5), 54-61$. Retrieved from http:// www.iosrjournals.org/iosr-jbm/pages/v10i5.html Mahardian, P. (2008). Analisis pengaruh rasio CAR, BOPO, NPL, NIM dan LDR terhadap kinerja keuangan perbankan (studi kasus perusahaan perbankan yang tercatat di BEJ periode juni 2002-juni2007). Tesis, 1-124.

Mintarti, S. (2009). Implikasi Proses Take-Over Bank Swasta Nasional Go Public terhadap Tingkat Kesehatan dan Kinerja Bank. Jurnal Keuangan Dan Perbankan, 13(2), 346-358.

Nawaz, M., Munir, S., Siddiqui, shahid A., TahseenUl-Ahad, Afzal, F., Asif, M., \& Ateeq, M. (2012). Credit Risk and the Performance of Nigerian Banks. Interdisciplinary Journal of Contempory Research in Business, 4(7), 49-63. 
Negara, I. P. A. A., \& Sujana, I. K. (2014). Pengaruh Non Performing Loan Dan Capital Adequacy Ratio Terhadap Penyaluran Kredit. E-Jurnal Akuntansi Universitas Udayana, 9(2), 325-339.

Pahlevie, N. H. (2009). Analisis Pengaruh CAR, NIM, LDR,NPL, BOPO Dan EAQ Terhadap Perubahan Laba ( Studi Empiris Pada Bank Umum di Indonesia Periode Laporan Keuangan Tahun 2004 - 2007 ). Tesis, 214-221.

Prakash, Ravi Poudel, S. (2012). The impact of credit risk management on financial performance of commercial banks in Nepal. International Journal of Arts and Commerce, 1(5), 9-15. https://doi.org/10.5897/AJBM2013.7171

Raharjo, D. P. A., Setiaji, B., \& Syamsudin. (2014). Pengaruh Rasio CAR, NPL, LDR, BOPO, dan NIM Terhadap Kinerja Bank Umum di Indonesia. Jurnal Ekonomi Manajemen Sumber Daya, 15(2), 7-12. Retrieved from http://journals.ums.ac.id/index.php/dayasaing/ article/download/2047/1439

Ratna Setyaningsih, N., \& Herawati, T. D. (2014). Pengaruh Tingkat Kesehatan Bank Terhadap Perubahan Laba (Studi pada Bank Syariah di Indonesia Tahun 2010-2012). Jurnal Ilmiah FEB UB, (7), 1-20.

Respati/Harianto, \& Eri, Y. (2008). Tinjauan Tentang Variabel-Variabel CAMEL Terhadap Laba Usaha Pada Bank Umum Swasta Nasional. Jurnal Keuangan Dan Perbankan, 12(2), 283-295.

Sapariyah, R. A. (2012). Pengaruh Rasio Capital, Assets, Earning dan Liquidity Terhadap Pertumbuhan Laba pada Perbankan di Indonesia (Study Empiris pada Perbankan di Indonesia). Jurnal Ekonomi Bisnis dan Perbankan, 18(3).

Sinha, P., \& Dutta, D. (2011). M P RA Modelling profitability of Indian Banks Modelling Profitability of Indian Banks. Munich Personal RePEc Archive, (31156). Retrieved from http:/ /mpra.ub.uni-muenchen.de/31156/

Sumarno. (2014). Pengaruh Kinerja Keuangan Bank Yang Terdaftar di Bursa Efek Indonesia Terhadap Return Saham. Jurnal Ilmiah Akuntansi Dan Bisnis, 9(1), 49-56.

Suvita Jha, \& Hui, X. (2012). A comparison of financial performance of commercial banks: A case study of Nepal. African Journal of Business Management, 6(25), 7601-7611. https://doi.org/10.5897/AJBM11.3073
Thalib, D. (2016). Intermediasi, Struktur Modal, Efisiensi, Permodalan dan Risiko terhadap Profitabilitas Bank. Jurnal Ekonomi Dan Perbankan (JKP), 20(1), 116-126.

Widati, L. W. (2012). Analisis Pengaruh CAMEL Terhadap Kinerja Perusahaan Perbankan Yang Go Publik. Dinamika Akuntansi Keuangan Dan Perbankan, 1(2), 105-119. Retrieved from http://www.unisbank.ac.id/ojs/index.php/fe9/ article/view/1590

Wijaya, A. P. (2013). Analisis Rasio Keuangan Dalam Merencanakan Pertumbuhan Laba/: Perspektif Teori Signal. Kajian Ilmiah Mahasiswa Manajemen, 2(2). Retrieved from http:// portalgaruda.org

Yogi Prasanjaya, A. A., \& Ramantha, I. W. (2013). Analisis Pengaruh Rasio Car, Bopo, Ldr dan Ukuran Perusahaan Terhadap Profitabilitas Bank Yang Terdaftar di Bei. E-Jurnal Akuntansi Universitas Udayana, 4(1), 230-245.

Abdullah, Thamrin dan Francis Tantri. 2014. Bank dan Lembaga Keuangan. PT. Rajagrafindo Persada. Jakarta. Cetakan ke-3

Afanasieff, T. S., Lhacer, P. M., and Nakane, M. I. 2002. The determinants of bank interest spread in Brazil. Money Affairs, 15(2), 183-207.

Andayani, Putu Novi, Yuniarta, Gede Adi dan Sujana, Edi. 2015. Pengaruh Kecukupan Modal, Kualitas Aktiva Produktif, Rentabilitas, Dan Likuiditas Terhadap Pertumbuhan Laba (Studi Kasus Pada Lembaga Perkreditan Desa Kabupaten Buleleng). e-Journal S1 Ak Universitas Pendidikan Ganesha. 3(1)

Artha. I Made. 1999. Penilaian Tingkat Kesehatan LDKP/LPD. Bank Pembangunan Daerah Bali Kantor Pusat Denpasar.

Biro Perikonomian Dan Pembangunan Sekretariat Daerah Provinsi Bali. 2012. Pedoman SOP Administrasi LPD.

Dendawijaya, Lukman. 2000. Manajemen Perbankan. Jakarta: Penerbit Ghalia Indonesia.

Gubernur Bali. 2012. Peraturan Daerah Provinsi Bali Nomor 4 Tahun 2012 tentang Perubahan Kedua Atas Peraturan daerah Provinsi Bali Nomor 8 Tahun 2002 tentang Lembaga Perkreditan Desa.

Hanafi, Mambuh M. 2009. Manajemen Risiko: Edisi kedua. Yogyakarta: UPP STIM YKPN

Mahendra, A. S., dan Rahardjo, S. N. 2011. Analisis Faktor-Faktor Yang Mempengaruhi Perubahan Laba Pada Perbankan di Indonesia. Doctoral dissertation, Universitas Diponegoro. Semarang. 
Ramantha, I Wayan. 2008. "Menuju Lembaga Perkreditan Desa (LPD) Bali yang Lebih Sehat: Suatu Kajian Struktur Pengendalian Intern". Paper disajikan pada Orasi Ilmiah Pidato Pengukuhan Jabatan Guru Besar Tetap Dalam Bidang Sistem Informasi Akuntansi pada Fakultas Ekonomi Universitas Udayana, Denpasar.

Sastrosuwio, Suminto, and Yasushi Suzuki. 2012. The Determinants of Post-Crisis Indonesian Banking System Profitability. Economic and Finance and Review I (1), pp:48-57.
Sapariyah, R. Ani. 2012. Pengaruh Rasio Capital, Assets, Earning Dan Liquidity Terhadap Pertumbuhan Laba Pada Perbankan di Indonesia (Study Empiris Pada Perbankan di Indonesia).Jurnal Ekonomi Bisnis dan Perbankan, 18(13).

Setyaningsih, N. R., dan Herawati, T. 2014. Pengaruh Tingkat Kesehatan Bank Terhadap Perubahan Laba (Studi pada Bank Syariah di Indonesia Tahun 2010-2012). Jurnal Ilmiah Mahasiswa $F E B, 2(2)$ 